\title{
PORTUGUESE LINGUISTIC COLONISATION AND LANGUAGE POLICY: BRAZIL AND MOZAMBIQUE, BETWEEN DIVERSITY, INEQUALITY AND DIFFERENCES
}

\section{COLONIZAÇÃO LINGUÍSTICA PORTUGUESA E POLÍTICA LINGUÍSTICA: BRASIL E MOÇAMBIQUE, ENTRE DIVERSIDADE, DESIGUALDADE E DIFERENÇAS}

Bethania Mariani $^{1}$

\begin{abstract}
Resumo: Este artigo discutirá conceitualmente as distinções entre diversidade, desigualdade e diferença em relação à língua portuguesa de dois países que passaram por processos de colonização linguística. Para este fim, pretende apresentar mudanças no sentido da língua portuguesa durante o processo de colonização e no período pós-independência no Brasil e em Moçambique.
\end{abstract}

Palavras-chave: colonização linguística no Brasil e em Moçambique, política linguística, desigualdade e diversidade linguística, sentidos da língua portuguesa.

\begin{abstract}
This article aims to discuss conceptually the distinctions between diversity, inequality and difference in relation to the Portuguese language of two nations that underwent processes of linguistic colonisation. To do so, it intends to present shifts in the meaning of the Portuguese language during the colonisation process and the post-independence process in Brazil and Mozambique.
\end{abstract}

Keywords: Linguistic colonisation in Brazil and Mozambique, Language policy, Linguistic inequality and diversity, Meanings of the Portuguese language.

\section{Initial theoretical considerations}

The title of this article relates to two aspects that underpin it: a theoretical position from which it aims to discuss linguistic colonisation and language policy, and a timely presentation of analyses of language policies and legislation aimed at regulating linguistic diversity, whether to defend it or to reduce it to a state of monolingualism. These language policies, in their historicity, retain memories that can be brought into the present when other policies and laws are formulated to promote new interventions in relation to the languages in a given context.

The theoretical position brings together two fields of knowledge production: History of Linguistic Ideas and Discourse Analysis. Both situate the researcher between the Humanities and Social Sciences since they do not separate language from history. They are fields of knowledge that link the production of meanings to the historical and ideological conditions of this production. Consequently, language policies will be examined bearing in mind analyses of historical situations of linguistic conflict that encompass the meanings of the language of colonisation and the national language.

A theoretical distinction firstly needs to be established: the use of the expression 'language policy' (Guimarães, 2002 and Orlandi, 2001) as a way of engaging with the

\footnotetext{
${ }^{1}$ Universidade Federal Fluminense - UFF, Niterói, Rio de Janeiro, Brasil; https://orcid.org/0000-0001-93331439; bmariani@id.uff.br
} 
aforementioned fields of knowledge. 'Language policy' relates to a way of conceptualising a 'language': language as a political-symbolic object that is both inscribed in socio-historical practices and inscribes socio-historical practices affected by memory in its materiality, which is linguistic. Here the national language is not disassociated from the historicity of the constitution, organisation and functioning of Nation States. Regarding the field of History of Linguistic Ideas, it is relevant to discuss the production of discourses that constitute tacit knowledge or knowledge that is given the status of scientific knowledge about national languages. What effects in terms of meanings do these discourses have on language policies?

Scholars of languages formulate knowledge about languages, representations that can be tacit or examples of the production of scientific knowledge, via the detailed elaboration of descriptions, analyses, dictionaries and grammars, as well as the description of varieties, the attitudes of speakers towards diversity and so on. This production of knowledge is neither ahistorical or ingenuous, and has to do with the fact that, as scholars of language, we must accept that any production of knowledge about a language whatsoever stems from a theoretical position and has political effects on the knowledge produced. This means stating that any theoretical position is a political position since it is inscribed in epistemological compartmentalisations, and inscribes the knowledge produced within a particular paradigm. Given this is the case, our theoretical positions are political positions: theories, even if they do not make explicit a political position, carry with them differences that reveal this position. In the opinion of Guimarães, the notion of the political "lies at the heart of social relations, not in talking about but rather at the core of social and linguistic functioning and has to do with the places of enunciation, and not with empirical people." (Guimarães, 2002, p. 15)

To talk about language policy with regard to diversity, inequality and difference is to adopt a theoretical position that is very revealing of a particular concern: languages and the subjects who speak them are imbricated in this diversity, inequality and difference, but the functioning of diversity, inequality and difference is not always visible, in the overall social and historical context, to these subjects when they use the language. In terms of Discourse Analysis, using language is to inscribe oneself in the socio-historical functioning, in the processes of the production of meanings that circulate in relation to languages and subjects, and the memory of which, in the paradoxical interplay or remembering-and-forgetting, is not always present in a perceptible way. These two notions - the politics of language and language policy (Orlandi, 2001, 2009) - mark linguistic situations in which recognising linguistic diversity often only silences inequality and the confrontation between languages and speakers, thus silencing discussions of the resulting hierarchisations.

The following is an example of this: why do we speak Portuguese in Brazil? It seems a straightforward question, but it implies a return to a way of telling the history of Brazil that eliminates the diversity of indigenous languages, eliminating the historical and discursive reality of linguistic colonisation (Mariani, 2018). 'The Portuguese language' is an expression that offers another possible meaning to us Brazilians. On the one hand, we are faced with a concrete reality constructed and reinforced throughout four centuries of historical colonisation: our national language is Portuguese. However, when we state that, we are submitting to the discursive memory of colonisation (which began in 1500) and the legal consequences of the Marquis of Pombal's edict (passed in 1757), as we will go on to discuss. On the other hand, since the Independence of the former colony of Brazil (granted in 1822), and also following certain events, such as the production of a Portuguese grammar in Brazil, the Romantic and Modernist literary movements, and the emergence of linguistics as a discipline, the term Portuguese language has also led to other processes of signification: meanings return, but when they do so they have shifted and often they take the form of new meanings. In other words, as it is not possible to shed the historical injunctions of colonisation, and at the same time, as the 
Portuguese language on crossing the Atlantic was marked by a different historicity, a difference was established: we speak Brazilian Portuguese, we speak Brazilian.

For theoreticians, scholars of languages, as well as recognising them, is the defence of linguistic diversity effectively a way of eliminating historically constructed inequalities? What does the recognition of differences actually entail? First, it involves criticising the supposed homogeneity of a language. From this point of view, the recognition that the linguistic homogeneity of a national language is a fiction does not necessarily imply a criticism of the inequalities that such a fiction imposes. This is a political discussion that needs to be taken forward in contexts where the imposition of national language policies is being addressed. If the term Portuguese language preserves the memory of colonisation and the idea of language as a kind of untouchable Portuguese legacy, designating the spoken language as Brazilian Portuguese or as the Brazilian language gives rise to meanings that move away from official history and allow the historical-linguistic heterogeneity of the formation of the national language to surface. The name of the language is, therefore, a question of language policy and State politics.

\section{Linguistic colonisation}

Within the field of studies of national languages, the processes of historicising languages are analysed. In the process of constructing the identity of a language as a national language, it is necessary to take into account how it has been historicised, i.e. the confrontations it has encountered with other languages, the events that have affected its trajectory in the social context it belongs to, and, furthermore, how a linguistic memory has been created around this mark of identity.

This approach has given rise to the notion of linguistic colonisation.

The term linguistic colonisation (Mariani, 2018) relates to the results of a linguistic event in the trajectory of nations with different languages and memories without previous contact. It refers to a historical process of confrontation between languages with dissimilar memories, histories and politics of meaning, in asymmetrical power dynamics, such that the colonising language has the political and legal conditions to impose and legitimise itself in relation to the other colonised language(s). Linguistic colonisation is confrontation. A confrontation in which some meanings are deconstructed and many others are constructed, imposed and emphasised in very particular historical-enunciative circumstances, which gradually engender the rise of a national language and subjects that use a language of colonisation to give meaning to themselves.

In this historical context of contact and confrontation between two or more languages, in a specific period of co-existence and dispute over spaces of communication - like the situation of vernaculars asserting themselves in relation to Latin throughout the Middle Ages, or in a colonial context, like that of the Portuguese colonies or, in addition, in a postcolonial context -, what we are dealing with is a dispute between the politics of meaning of the languages in question.

Within the politics of linguistic contact-confrontation, a very complex historical situation comes into play, about which one could ask the following question: "What meaning(s) will subjects use to signify the practices of their daily lives?" At the same time, as the contact continues, linguistic elements migrate between languages, adapting or even transforming these languages. In the same way, aspects that constitute the production of meanings can also migrate from one language to another, whether reorganising the historically constituted ways of saying things in one of these languages, or moving into other symbolic systems that are not purely linguistic. 
Discussing the introduction of a linguistic policy entails understanding, initially, the way the complex historical-linguistic context operates, the latter constituting the fundamental material conditions for the stances adopted by institutions of power, aiming to regulate linguistic practices. Within the discursive perspective proposed here, the emergence of language policies is understood as the result of an attempt to organise signifying practices and the social forces that are at stake. There is a technical aspect, a restrictive presupposition in the formulation of linguistic policies, an element that regulates the effective use of a language or the silencing of another, simultaneously regulating the institutional spaces where languages circulate and the way they do so. In this respect, seeking to domesticate the transit of linguistic heterogeneity, a language policy serves to regulate the language that subjects will use to signify their history.

In summary, an unspoken objective, although one that is achieved via a language policy, is the regulation of the meanings and histories that are circulating and will constitute the memory of the colony in relation to the colonial power. In the name of a language policy, a policy of silencing is established that aims to achieve unity, clarity and understanding in communication. This silencing influences the politics of signification of languages or, at least, the politics of signification of one of the languages that finds itself in contact with another.

\section{Linguistic colonisation in Brazil}

When considering the relationships of signification between languages in colonised countries, the history of the construction of the fiction of national linguistic homogeneity is evidenced in the struggles for Independence, and the constitution of the nation-state; and in the power relations between subjects living in these historical conditions; in the production of grammars, dictionaries, basic linguistic tools for the gramaticalisation of languages. (Auroux, 1992, Orlandi, 2002, Mariani, 2018)

There are historical conditions that constitute not only an image of the unity of languages, but also provide the possibilities for subjects who speak these languages to identify or not with this imagined linguistic unity. Consequently, a language may be national and official, creating an image of unity; and, at the same time, linguistic diversity may be recognised but, in its concrete discursive praxis (in other words, in its daily production of meanings), and in the processes that legally institutionalise the national language and recognise this diversity (I am referring here to the diversity recognised in the national Constitution), what occurs is the reassertion of inequality.

When we talk about linguistic colonisation and language policy (Mariani, 2018) we are referring to the linguistic ideas that used to circulate in Europe and that impregnate colonising discourses found not only in the accounts of travelers and missionaries who went to the New World, but also in the so-called historical accounts that, often commissioned, were tasked with telling the history of Brazil. Between the 16th and 18th centuries, this body of texts, characterised by repetitions and comments, constituted a historical discourse about the process of colonisation, allowing, between the lines, for different meanings to be attributed to linguistic heterogeneity, especially in relation to that of the indigenous peoples. This discourse also allows us to glimpse language policies that were established with the arrival of European languages, Portuguese and Latin, as well as Spanish and French.

Although the question of diversity of languages is not the central theme of these texts, in them the need to know indigenous languages is inferred. Knowing these people and their languages, in practical terms, represented one of the keys to achieving total conquest, expansion and colonisation of the territory. The linguistic colonisation engendered by the colonial power, Portugal, was organised around an ideology of cultural and linguistic deficit, a deficit that, at 
the same time, was postulated as already existing prior to the moment of colonial contact, and thus served to legitimise the way that domination was undertaken. Consequently, since Pero Vaz de Caminha's Letter and the first descriptions produced by missionaries like the priests Father Anchieta, Gândavo, Fernão Cardim and Ambrósio Brandão, amongst others, a meaning for the lack that was already presumed to exist was found and proven linguistically: the letters $F, R$ and $L$ did not exist in the indigenous language and this evidenced the absence of a religious authority, a central royal power and of a legal administration ${ }^{2}$. Languages are thus the object of linguistic observations and, simultaneously, the process of describing them reifies a particular, previously constructed, linguistic-cultural image.

From the perspective of the Portuguese coloniser, these three underpinning institutions of State apparatus - religion, royalty and the law - symbolise an advanced stage of civilisation that is rooted in a single national language with a grammar and written form. From this perspective, the Portuguese language is also an institution that is part of the overall social functioning of the nation, at the same time as providing written legitimisation for the other institutions of the kingdom. The inhabitants of the colony and their languages, therefore, are not civilised because they are deemed as lacking what the Portuguese possess and consider central to civilisation. In this way, a linguistic theory (the theory of the deficiency of indigenous languages) legitimises a religious theory (the lack of a single god) and another of a politicallegal nature (the lack of laws and of a king). From the starting point of language, a vision of a deficiency in terms of civilisation is constructed as a justification for colonial expansion.

The construction of this initial knowledge about the indigenous languages spoken in the Brazilian colony, a knowledge marked by European ways of thinking, was responsible for maintaining a particular evolution of meanings for the languages in circulation within the colony. An initial locus of signification (Orlandi, 2001) about indigenous languages was therefore established, which both enabled countless repetitions and paraphrases of this imagined linguistic deficiency and justified the ideology of the superiority of European languages, and more specifically, Portuguese. Such a locus of signification enabled, with the crystalisation of the interpretative gesture that it symbolised, the naturalisation of this notion of lack in relation to indigenous languages and the people who speak them: both will go on to be heard and described, in other words, interpreted as evidence of this precariousness and this deficiency.

Analysis of these historical texts about languages has allowed us to identify a type of reasoning that constructed a form of knowledge about "things from Brazil", its inhabitants and the languages that circulated there. In this way, it is possible to witness the different levels of status attributed to languages and to the discursive positions occupied by their speakers. These texts have also evidenced the conflictive co-existence of the Tupi 'general language', the other indigenous languages, the Portuguese language and the other European languages that circulated in Brazil in that period.

The $18^{\text {th }}$ century brought with it a drastic change: the Tupi 'general language' (lingua geral), a title given by the Jesuits, which was widely used throughout all the captaincies - both in the towns and cities and in the sugar mills and plantations - was banned, silenced by the same colonial policy shift that expelled the Jesuits from the colony. On 3 May 1757, the Indian Directorate was introduced ("A Directorate that must be observed in the settlements of the indigenous people of Pará and Maranhão"), and Portuguese was imposed by the Portuguese Crown as the exclusive language of the colony, alongside the official banning of the 'general language'.

In Paragraph 6, we can read the royal order conveyed in the Indian Directorate:

\footnotetext{
${ }^{2}$ In Portuguese, the words Fé [faith], Rei [king], Lei [law] begin with F, R, L.
} 
It has always been a maxim unalterably practised in all nations who have conquered new Dominions, to introduce straight away their own language to the conquered Peoples, since it is indisputable that this is one of the most efficient ways to rid backward Peoples of the barbarity of their former customs; and experience has shown that, at the same time, introducing them to the use of the Language of the Prince who conquered them also instils them with affection, veneration and obedience to this same Prince. All civilised Nations of the World thus observing this wise and solid system, in this Conquest the reverse was practised, with the first Conquerors establishing the use of the Language that they called the general [language]; a truly abominable and diabolical invention, leaving the Indians deprived of all those means that could civilise them, in the continued state of backward, barbaric subjugation that they still find themselves in. To rid them of this most pernicious abuse, one of the principal measures of this Directorate is to establish in their respective settlements the use of the Portuguese Language, and it will not be permitted in any circumstances for Boys and Girls who attend the Schools, and all those Indians who are capable of being taught this subject, to use the Language of their own Nations, or the other known as General [language]; they will only be able to use Portuguese in the manner than your Majesty has recommended in repeated Orders, which until now have not been observed causing total Spiritual Ruin and Temporal Ruin of the State. (Documentos vários do Maranhão e Grão Pará. 1719-1809. Volume 9. Rio de Janeiro, Instituto Histórico e Geográfico do Brasil.)

The Directorate, a set of rules that aimed to impose order via various authorities on the conduct of the colonisers in the northern region of the colony, was implemented by the Governor of the Captaincies of Grão-Pará and Maranhão, Francisco Xavier de Mendonça Furtado, the Marquis of Pombal's brother. On 17 August 1758 a king's charter extended its reach and application to the entire colony. The Directorate was only effectively overturned forty years later, via another royal charter issued on the 12 May 1798.

It is evident that the Directorate was part of a historical imaginary underpinned by the desire for a universal vision that linked together language and the conquering and conquered nation. The meaning of (official) language here is the language of a colonising power, in this case the Portuguese, aligning themselves with other civilised nations. Language is no longer a catechetical tool, but exclusively a constitutive element of European civilisation, an inclusive civilisation, in other words, one which wants to incorporate via the imaginary the indigenous people as subjects. We could even go as far as saying that civilisation and nation here do not have the same meaning for the Portuguese and for the Jesuits, even though they are meanings from the same language, Portuguese. Another important point to emphasise is that the meaning of the Portuguese language as the language of conquest brings with it a memory that is already inscribed in the first grammars of the Portuguese language: "It is better that we teach Guinea than we learn from Rome." (Fernão de Oliveira, 1575)

From the perspective of royal power, the imposition of Portuguese as the only language to be spoken and taught in the colony represents the possibility of transparency and control of the colonised subject. Furthermore, it aims to achieve transparency in the management of daily life in the Brazilian colony from the $18^{\text {th }}$ century.

The important point is to understand that this imposition produced effects, namely: the effect of homogeneity (or the fiction of homogeneity or monoglossia); the effect of evidence (here Portuguese has always been spoken); and the silencing of indigenous languages. This language policy established in the $17^{\text {th }}$ century had reverberations for the Brazilian State in the 
centuries that followed, in the form of polemics between grammarians and men of letters, between grammarians and linguists.

Following the declaration of Independence in 1822, the question of the national language provoked discomfort in speeches about the spoken language. Was the language to be signified as continuity or rupture? As nostalgia or the establishment of something new? (Mariani and Jobim, 2006). In these speeches, the ideologues of Independence, those that belonged to the elite, constructed meanings to create a nationalism that relied on being signified in what was the language of the coloniser. I use the past tense here - "was the language of the coloniser" since, in fact, as well as morphophonological and lexical alterations, in addition to the discomfort that its use would cause in the speeches of the ideologues, ${ }^{3}$ we must bear in mind that there was a process of resignification of the language of the coloniser as national language in terms of its symbolism.

Throughout the $19^{\text {th }}$ century, during the years of the independent nation, the name of the language of Brazil was discussed: Brazilian language? Brazilian Portuguese? Portuguese language? The specificity of the spoken language was also debated, for example by the novelist José de Alencar, an ardent defender of the Brazilian language. Alencar states: "The people who suck the cashew fruit cannot speak in the same way as the people who drain the loquat". (Alencar, preface to Sonhos d'Ouro). However, in this period, the idea of an imagined unity covering the entire nation was not yet discussed: evidence that Portuguese is spoken in Brazil is not even written in to the first constitution of the Empire.

In terms of Brazil, there is a tension in the political speeches that aimed to confer this quality of belonging to a certain place: the spread of ways of speaking Brazilian Portuguese added to the countless indigenous languages and the persistence of a political-ideological desire for unification that necessarily depended on the constitution of a homogenous national language. Administrating the territory of Brazil as an Empire or as a Republic was a political but also a linguistic process that was carried out with the development of linguistic knowledge about a desired national language.

Furthermore, the constitution of the nation, especially after the advent of the Republic, corresponded to a process of social transformation. How could the title 'Brazilian' be given to a language of colonisation in a modernising nation? In 1935 and 1946 the question of whether to refer to it as the Portuguese or the Brazilian language was raised again in the form of legal resolutions and bills (Dias, 1996), illustrating the extent to which political-discursive demands to cement a national language and a linguistic nationalism were still in evidence. To refer to the national language as the Brazilian language was to defend the idea of a common language, with the "effect of bringing together individuals from the same territory without calling into question the participation of these individuals in the nation" (Dias, 1996, p. 75).

This desire for an imagined linguistic unity in relation to the spoken language, added to the idea of national unity, materialised ideologically in the first years of the Republic in two congresses that took place in the early $20^{\text {th }}$ century: the congress of the Sung Language in 1937, and that of the Language Spoken in the Theatre, in 1956. (Mariani, 2010) Here we can see the embryo of a language policy being gestated in academic circles. The First Brazilian Congress on the Language Spoken in the Theatre (Salvador, 1956) chose the Portuguese spoken in Rio de Janeiro as the standard pronunciation, and the grammarian Celso Cunha (1958), in his programmatic opening speech, defended the image of unity:

The peculiar conditions of our linguistic formation reveal a dialectization that does not appear to be as varied, as multiple and as longstanding as that which has existed in several European countries. (...) If this characteristic seems valid

\footnotetext{
${ }^{3}$ See, for example, the words of politicians in 1823 , the dispute over the name of the national language, the polemics in the literary sphere and so on.
}

Rev. Bras. Lit. Comp. Niterói, v. 22, n. 41, pp. 03-14, set. /dez. 2020

https://doi.org/10.1590/2596-304X20202241bm 
for cultural laboratories like Asia, Europe and even Africa, it does not seem less so for the countries of the Americas, whose pre-European linguistic past has left few traces in the present. (...) it seems that we are on the threshold of a socio-political era in which the major national languages tend to progressively display a much broader relative unity than seemed possible in even the recent past. (...) a nation that due to the social and economic characteristics of the modern world, tends progressively towards a great sense of unity, without the hindrances of a regional traditionalism entrenched over many centuries. (Cunha, 1958, p. 15).

Therefore, in the view of the grammarian Celso Cunha "the establishment of a standard language will be yet another civilising element and a cultural process". In his inaugural address at the conference, recalling the Congress of the Sung Language, held in 1937, he said that there were lessons to be followed: 1) "a patriotic factor of national unity"; 2) "the pronunciation of Rio de Janeiro is the most evolved of the regional pronunciations of Brazil, the quickest and the most incisive, the one with the greatest musicality in oral pronunciation, the most elegant, the most essentially urban"; and, finally, 3) that "for having been established in the capital of the country, an unconscious product, a synthesis resulting from the collaborations of all Brazilians and for this very reason more adaptable to all of them" (Cunha, 1958).

Being used in the theatre, and gradually by all Brazilians, a unique intervention would take place in relation to the fluid language that was the dream of some grammarians at that point in history. Something that went beyond the idea of that ONE language set in the moulds of the imaginary language that Orlandi refers to (2009). If these guidelines had become law, perhaps this would have been a decisive intervention in relation to the language spoken in Brazil.

Furthermore, grammarians and many intellectuals turned their attentions to the diversity of dialects, recognising linguistic-cultural variation during the proceedings of the First Congress of Dialectology, which took place in Porto Alegre, in 1958. Candido Jucá (junior)'s Brazilian Linguistic-Ethnographic Questionnaire, presented and discussed during the congress, is very explicit: "Evidently, the way cultured people speak is not the issue here. What we seek to know is how ordinary people speak" (Jucá, 1958, p. 5). Unity as opposed to diversity, that is the central theme of the three congresses $(1937,1956$ and 1958).

The excerpts presented here illustrate the political tension between the fluid, variable language, whose meanings shift, and the imaginary language, set in the moulds of grammar books: Within the ideology of the unity of the national language, as Orlandi states, "the grammarian creates the idea of ONE language regulated for all Brazilians and shows the deviations, differences (varieties), in (national) uniformity..." (Orlandi, 2002, p. 206).

\section{Language policy today and the effects of linguistic colonisation}

Let us consider some examples. In Lisbon airport (in 2012 and 2013) a language policy could be seen in action: a sign indicated an immigration line specifically for members of the Community of Portuguese-speaking Countries. However, the booth for this line was closed. Official UN and UNESCO documents in principle defend language diversity, but in practice inequality is re-instated: "all languages are accepted as working languages, but the official languages are...". Another situation that illustrates recognition of diversity, but that maintains inequality is Paraguay's bilingual policy. Spanish and Guarani are the official, national languages, but little Guarani is taught in schools. In Brazil, in the small town of São Gabriel da Cachoeira, the local council has established that the official language is Portuguese, and at the same time, three indigenous languages have also become official: Nheengatu, Tukano and Baniwa, languages traditionally spoken by the majority of the inhabitants, over $85 \%$ of whom 
are indigenous. Undoubtedly, making three indigenous languages official is to admit, according to the Brazilian Constitution of 1988, that Brazil is a multilingual country (there are 180 indigenous languages still in existence and some 25 to 30 immigrant languages). However, making an indigenous language official should trigger a piece of legislation that is part of the Law of Education Foundations and Guidelines (1996) in Brazil. This Law enshrines free, compulsory bilingual teaching, with adequate didactic material - grammars and dictionaries. But without an adequate language policy, the official status given to Nheengatu, Tukano and Baniwa does not imply an effective use of these languages (in schools, newspapers, official documents etc).

Official recognition of linguistic diversity in the Brazilian Constitution does not minimise the effects of linguistic inequality. As I have discussed elsewhere (Mariani, 2008), there is an enormous difference between the standardised language of grammar books and the Brazilian Portuguese spoken in everyday life. Linguistic recognition of the differences between these varieties, however, is not sufficient to eliminate inequalities. There is thus a strange paradox concerning speakers of Brazilian Portuguese: they say that they cannot speak Portuguese. By saying that they do not know how to speak their own mother tongue, these speakers inscribe themselves in a language policy that silences social and regional linguistic differences in the name of a normative official language set down in the grammar books. These Brazilians do not therefore identify with the standardised language that is taught in schools, the official, linguistically normative variety, which is considered difficult, abstract and far removed from their everyday lives. This Portuguese language legally designated as the official language in the Brazilian Constitution, effectively an example of monoglossia (Zandwaiss, 2011) that silences the historical processes that created the relationship between the official language and the constitution of the national State of Brazil, leads many Brazilians not to identify with this language.

\section{Linguistic Colonisation in Mozambique}

Mozambique, as a colony of Portugal, did not undergo a process of linguistic colonisation similar to that of Brazil. It was only following the Conferences of Berlin (1885) and Brussels (1887), which determined the carving up of Africa between the European powers based on uniform international rules regarding territorial occupation, that Portugal, as a result of this international political repositioning, began to more vigorously administrate its Overseas territory via socio-educational measures that aimed to actually occupy and civilise the African peoples through the introduction of Portuguese language and customs.

As I have already discussed elsewhere (Mariani, 2011, 2012 a e 2012b), decrees passed in 1845 and 1869 created a new education system, one that "defined the different types of education to be given to Africans and Europeans" (Ferreira, op. cit., p. 63). Towards the end of the $19^{\text {th }}$ century, new Portuguese Catholic missions headed to Africa and estabished missionary schools for the Portuguese who were living there, and for the Africans, in particular. In terms of religious policy, the approach was identical to that of previous centuries: "Those responsible for the mission schools were above all concerned about converting people. (...) Teaching was generally conducted through the local African language, and sometimes in Portuguese" (Mariani, 2011, p. 65). It was therefore from the end of the $19^{\text {th }}$ century onwards that Portugal actually began to implement a language policy that aimed to make Portuguese the hegemonic, civilising language.

Any colonising language, with the passage of time, is altered not only by contact with other languages, because it has moved away from its mother country, but also due to the processes of resignification that come into play as part of colonisation. Although there was no investment in creating grammars of Bantu languages, or, until the $20^{\text {th }}$ century, in the 
implantation of Portuguese among the overall population, at the time of the revolution and in the post-revolutionary period, the complexities of the linguistic question were addressed by the members of the Mozambican Liberation Front (FRELIMO): How should the people of Mozambique speak in and to the modern world? The historicisation of the Portuguese language, at that moment when the struggle for decolonisation took another turn: the image of the language of independence was added to the image of the language of the coloniser. As an official language, could this language of the former coloniser be considered a national language (Firmino, 2006, p. 45)? After all, if it is a language chosen to bring the nation together, was Portuguese a language that all Mozambicans identified with? The Portuguese language never succeeded in becoming the national language in Mozambique, or rather, a mother tongue associated with nationality.

From this perspective, the case of language policy in Mozambique in the postindependence, post-revolutionary period (Mariani, 2012) poses a range of different thoughtprovoking questions. On the one hand, the Portuguese colonising discourse established language policies that led to censorship, local silencing (Orlandi, 1984), and an ideological submission of the Bantu language to the Portuguese language. Revolutionary discourse, in turn, initially established a language policy that aimed to create a new man in a new unified Mozambican society. To do so, and without discrediting the native languages, it established Portuguese as the official language.

In the 1970s, an intervention on the part of the Mozambican State in relation to FRELIMO's policy sought to regulate the way in which Mozambicans related to the languages in circulation, but it could not eliminate the particular way that elites and ordinary people attached meaning to these languages. It was not enough to simply state that "The overall orientation defined by the FRELIMO Party and by the Mozambican Government considers the Portuguese Language to be an element of national unity". A political statement such as this in an emerging plurilingual State does not wipe out the memory of colonial struggles chiefly inscribed in the meanings that the Portuguese generally attached to the Bantu languages and to the Portuguese spoken by Mozambicans: the Portuguese spoken by native Mozambicans was pejoratively called "pretoguês" (a pun on the words preto, meaning black, and português, Portuguese) (Firmino, 2005). Added to the memory of Portuguese as the language of the coloniser was the memory of a language that was allegedly 'spoken badly' by Mozambicans. How could such a memory be re-written to make Portuguese the official language of Mozambique, as the revolutionaries intended? They believed it would be possible to make Portuguese 'Mozambican'. Over three decades would pass before other language policies established a Bantu language as the nation's official language, and a bilingual education system was introduced.

History and language thus impact on each other and demonstrate the contradictions of the post-revolutionary period, illustrating the impossibility of legislating on unfeasible administrative-linguistic planning. There is Always something beyond the limits of planning; something that remains unfeasible.

\section{Final reflections}

The historicising of the Portuguese Language in Brazil and in Mozambique is not without its contradictions in the way the language has been signified. The meanings of the Portuguese Language have historically ranged from the language of the coloniser and the catechism, the language of the Independence movement, the official language and the language that does not represent national identity. The linguistic colonisation of the two colonies was not conducted in the same way and the implantation of Portuguese as the official language depended on decrees, on a process of grammaticalization and on the implementation of its 
teachings in schools. If linguistic colonisation silenced indigenous languages, decolonisation slowly fostered at least two processes in the two former colonies: discussion of the name and the meanings of the language spoken there and a language policy that aimed to grammaticalise the indigenous language(s) with a view to really reflect the social formation of the two States.

A language is a social institution. As Orlandi $(2009,175)$ reminds us: "the unity of the State manifests itself in and via institutions". Given this, fostering the genuine political representation of indigenous languages is a step towards recognising inequality and beginning to implement a true bilingual education system.

When a language policy is established, how much is a language worth? There are substantial alterations in this 'linguistic value' from colonisation to decolonisation. In the $20^{\text {th }}$ century, the trend has been to do away with language policies, especially in these neo-liberal times, when the economy takes precedence over politics... and languages. New configurations of meanings have materialised in the organisation of languages in the consumer market, giving rise to a strange language market: defend diversity? How?

In the last few years a number of books have been published that relate Linguistics to Economics (Mariani, 2005). The economists Bloom and Grenier (1992) identify a multiauthored publication from 1965 as the starting point of a new area of study: languages as an economic variable. If language is signified as an economic variable, whether by linguists or by economists, this enables them to be considered as an additional element in real or projected economic scenarios, with costs and benefits to be calculated. What are the political implications and the ideological consequences of considering languages as an economic variable?

The following question has previously been posed: what does it mean to talk about languages in economic-financial terms? Bearing in mind that there is no language without the people who speak it, would attributing economic values to languages not also determine the value of a society and the value of the speakers, both in the case of a mother tongue and a second language? What does this mean for languages as symbolic elements of nationhood? Would linguistic prejudice lead to linguistic prejudice between nations?

There is a particular political-economic discourse in circulation that proclaims the benefits and the inevitability of globalisation in the form of a single, worldwide market, with a common currency and a common language. Totalitarian dreams that hark back to the idea of inventing a 'basic English' in previous centuries... Totalitarian dreams of a single language, the elimination of diversity and the maintenance of inequality, ignoring the fact that difference is inherent to people and to the languages that they speak.

\section{WORKS CITED:}

AUROUX, Sylvain. A revolução tecnológica da gramatização. Campinas: Ed. Da UNICAMP, 1992.

BLOOM, David E. and GRENIER, Gilles. Economic perspectives on language: the relative value of bilingualism in Canada and the United States. In CRAWFORD, James. Languages Loyalties; a source book on the official English controversy. Chicago \& London: The University of Chicago Press, 1992. ISBN 0-226-12016-3

BRANCO, Luiza Castello. A língua em além-mar: sentidos à deriva: o discurso da CPLP sobre a Língua Portuguesa. Doctoral thesis, IEL, UNICAMP, 2013.

CUNHA, C. Discurso programático. In: Anais do primeiro congresso brasileiro de língua falada no teatro. Rio de Janeiro: MEC, Biblioteca Nacional e Universidade da Bahia, 1958.

FIRMINO, Gregório. A questão linguística na África pós-colonial. O caso do Português e das línguas autóctones em Moçambique. Maputo: Texto Editores, 2005.

GUIMARÃES, Eduardo. Semântica do acontecimento. Campinas, Pontes, 2002. 
JUCÁ (junior), C. Questionário linguístico-etnográfico brasileiro. Type-written text. Porto Alegre, 1958.

MARIANI, Bethania. Colonização linguística. New York: Peter Lang, 2018.

. Língua nacional e pontos de subjetivação. Revista do GEL (Araraquara), v. 01, 2008, p.

XXXVII-XXXX.

Da colonização linguística portuguesa à economia neoliberal: nações plurilíngues. Gragoatá (UFF), v. 24, p. 71-88, 2008.

Quanto vale uma língua? Custo e benefício político nas relações econômicas e linguísticas. In: Santos, Ana Cristina dos; Almeida, Claudia; Pontes Jr., Geraldo (eds.) Relações Literárias Internacionais II; Interseções e fricções entre fonias. Niterói, Rio de Janeiro, Editora da Universidade Federal Fluminense \& de Letras, 2008.

. Unidade idealizada na variedade concreta: censos linguísticos, congressos sobre a língua falada e normas da pronúncia padrão. In: MARIANI, Bethania; MEDEIROS, Vanise Gomes de. (ed). Ideias linguísticas: formulação e circulação no período JK. 01ed.Campinas: RG Editora, 2010, v. 01, p. 64-74.

76, 2011.

Uma revolução e seus impasses linguísticos: Moçambique. Letras (UFSM), v. 42, p. 56-

. Discurso revolucionário moçambicano e a escrita do homem novo. Via Atlântica (USP), v. 21, p. 59-74, 2012.

- Lusofonia, languages policies and formation of national states: mozambique. Portuguese Literary \& Cultural Studies, v. 1, p. 25-41, 2012.

MARIANI, Bethania and JOBIM, José Luis. National language and post-colonial literature in Brazil. Revista da ANPOLL, v. 20, p. 11-22, 2006.

Oliveira, Fernão de. Gramatica da linguagem portuguesa. Introduction, updated reading and notes by Maria Leonor Carvalho Buescu. Lisbon: Imprensa Nacional, 1975 (1575).

ORLANDI, Eni Língua e conhecimento linguístico. Campinas: Pontes, 2001. ISBN 85-2490877-7

ORLANDI, Eni (ed). História das Idéias Linguísticas: Construção do Saber Metalingüístico e Constituição da Língua Nacional. Campinas/Cáceres: Pontes/Unemat, 2001.

Língua brasileira e outras histórias. Discurso sobre a língua e ensino no Brasil. Campinas, RG Editora, 2009. . As formas do silêncio no movimento dos sentidos. Campinas, Pontes, 1984.

PÊCHEUX, Michel. A língua inatingível. Campinas, RG Editora, 2010.

ZANDWAISS, Ana. Práticas Políticas Nacionalistas e Funcionamento Discursivo: totalitarismo, fascismo e nazismo. In ZANDWAISS, Ana and ROMÃO, Letícia. Leituras do Político. Porto Alegre, Ed. Da UFRGS, 2011, pp. 127-142.

Bethania Mariani é Professora Titular do Departamento de Ciências da Linguagem da Universidade Federal Fluminense - UFF e Pesquisadora do CNPq. Mais informações em http://lattes.cnpq.br/3869834050601414

Submetido em 03/04/2020

Aprovado em 13/06/2020 